\title{
Effect of Activated Protein C (APC) on Apoptosis of Cancer Cells
}

\author{
Kyoung-jin Min', Jong-Sup Bae ${ }^{2}$ and Taeg Kyu Kwon ${ }^{1}{ }^{*}$ \\ ${ }^{1}$ Department of Immunology, School of Medicine, Keimyung University, Daegu 704-701, Korea. \\ ${ }^{2}$ College of Pharmacy, Research Institute of Pharmaceutical Sciences, Kyungpook National University, Daegu 702-701, Korea
}

Received March 12, 2012 /Revised March 26, 2012 / Accepted March 27, 2012

\begin{abstract}
Activated protein $\mathrm{C}$ (APC) has an anticoagulant effect and a non-hemostatic effect such as regulation of cell metastasis and modulation of inflammation. In this study, we investigated whether APC could modulate apoptosis in cancer cells. Tumor necrosis factor (TNF)-a , cyclohexamide, and FAS markedly induced apoptosis in human renal carcinoma Caki cells. When Caki cells were pretreated with APC, the percentage of death receptor-induced apoptosis did not change. Furthermore, we checked the effect of APC on tumor necrosis factor-related apoptosis-inducing ligand (TRAIL)-induced apoptosis in human glioma T98G and human breast carcinoma MDA231 cells. APC also had no effect on TRAIL-induced apoptosis in both cell lines. However, pretreatment with APC inhibited combination treatment (kahweol plus TRAIL and kahweol plus melatonin)-induced apoptosis and PARP cleavage in Caki cells. Taken together, our results suggest that APC can modulate anti-cancer therapeutic efficiency.
\end{abstract}

Key words : Activated protein C (APC), apoptosis, TRAIL, Caki cells, kahweol

\section{서 론}

과거 종양을 가진 환자에서 정맥혈전(venous thrombosis) 이 나타나는 것을 확인하였고, 그 이후 지속된 연구를 통하여 종양과 정맥혈전에 대한 상관관계를 밝히게 되었는데, 이는 종양을 가진 환자에서 종양이 없는 사람들과 비교 하였을 때 약 6 7배 이상으로 빈번하게 정맥혈전이 나타나는 것을 확인 하였다 $[5,6,17]$. 따라서, 최근 종양과 정맥혈전을 가진 환자들 을 치료하기 위하여 항응고제(anticoagulant)를 처리하는 방법 을 사용하고 있는데, 이는 정맥혈전뿐 아니라 종양치료에 효 과적인 결과를 나타내고 있다. 예를 들어 저분자량 헤파린 (low molecular heparin)을 종양을 가진 환자에게 처치를 하 면, 환자의 생명연장을 유도하고 사망률을 낮추는 결과를 가 져왔다[1,10]. 이는 혈액의 응고와 항응고에 관여하는 여러 가 지 인자들이 종양치료에 영향을 줄 수 있다는 것을 의미한다. 혈액의 항응고 작용에 관여하는 요소 중 activated protein $\mathrm{C}$ (APC)는 혈액응고에 관여하는 thrombin이 thrombomodulin과 세포막에서 결합체를 만들게 되면 이로 인해 protein $\mathrm{C}$ 로부터 $\mathrm{APC}$ 가 만들어지게 된다[8]. 이렇게 형성된 $\mathrm{APC}$ 는 factor $\mathrm{Va}$ 와 VIIIa의 활성을 억제시킴으로써 혈액응 고를 억제하게 된다[7]. 최근에는 혈액응고과정에서의 $\mathrm{APC}$ 기능뿐 아니라, 혈액응고와는 상관없는 다른 역할들이 밝혀 지고 있다. 예를 들면, $\mathrm{APC}$ 는 다양한 세포의 이동을 조절하 는 것으로 알려져 있는데 $\mathrm{APC}$ 를 인간 각질세포 (keratinocyte)에 처리하게 되면 세포의 분화와 이동을 증가

*Corresponding author

Tel : +82-53-580-3882, Fax : +82-53-580-3795

E-mail : kwontk@dsmc.or.kr
시키고, 이러한 효과는 metalloprotease-2의 활성을 증가시킴 으로써 나타난다[18]. 또한, 암세포에서의 $\mathrm{APC}$ 의 역할이 잘 알려져 있는데, 자궁암세포와 융모암세포, 그리고 유방암세 포에서 세포의 이동을 증가시킨다는 보고가 있다[2,11]. 하지 만, 최근 Bezuhly 등에 의해 수행된 연구를 보면 $\mathrm{APC}$ 가 endothelial protein $\mathrm{C}$ receptor (EPCR)이 과발현 된 경우 in vivo에서 오히려 흑생종암세포의 전이를 억제한다는 보고가 있어[3], $\mathrm{APC}$ 의 역할에 대한 연구는 그 기능을 이해하기에 미흡하여 더 많은 연구가 필요한 실정이다.

본 연구에서는 항응고제로 알려져 있는 $\mathrm{APC}$ 가 다양한 종 양치료 약물에 의한 종양세포의 사멸에 있어서의 그 기능을 파악하기 위하여 인간 신장암세포인 Caki 세포를 사용하여 그 효과를 확인하였다.

\section{재료 및 방법}

세포 배양 및 시약

본 연구에 사용한 신장암세포주인 Caki, 뇌종양세포인 T98G, 유방암세포인 MDA231세포는 American Type Culture Collection (ATCC, Rockville, MD, USA)에서 구입하 였다. 세포주 배양을 위한 배지는 $10 \%$ 태아우혈청(fetal bovine serum, Hyclone laboratories, Lagan, Utah, USA)과 1\% Antibiotics, $0.2 \%$ Gentamycin을 첨가한 DMEM (Dulbecco's Modified Eagle's Medium, Gibco BRL, Grand Island, NY)을 사용하였으며 $37^{\circ} \mathrm{C}$ 로 유지되는 $5 \% \mathrm{CO}_{2}$ 배양기를 이용하여 배양하였다. 실험에 사용된 약제인 TRAIL과 cyclohexamide 는 Sigma (St. Louis, MO, USA), anti-FAS는 Millipore (Bedford, MA), TNF-a는 R\&D Systems (Minneapolis, MN) 
에서 구입하였다.

\section{Flow cytometry analysis}

$1 \times 10^{6}$ 개의 세포를 $100 \mu 1$ 의 PBS를 넣어 잘 풀어준 후, 200 ul의 $95 \%$ ethanol 을 vortex하면서 조심스럽게 넣어준다. 세포 를 $4^{\circ} \mathrm{C}$ 에서 1 시간 동안 고정한 후, $\mathrm{PBS}$ 로 씻어준다. 세포에 $250 \mu \mathrm{l}$ 의 $1.12 \%$ sodium citrate buffer (pH 8.4)에 $12.5 \mu \mathrm{g}$ $\mathrm{RNase}$ 가 녹아있는 용액을 넣어 $37^{\circ} \mathrm{C}$ 에서 30 분간 배양하였다. 30 분이 지난 후 그 용액에 $250 \mu \mathrm{l} \mathrm{propidium} \mathrm{iodide}(50 \mu \mathrm{g} /$ $\mathrm{ml}$ )을 넣어 30 분간 RT에서 DNA를 염색하였다. 염색된 세포 를 FACScan flow cytometer (E5464, Becton Dickinson, USA) 를 이용하여 측정하였다.

\section{Western Blotting}

단백질의 발현을 알아보기 위해서 Western blotting을 실시 하였다. 세포를 $0.4 \times 10^{6}$ cells/well로 12 시간 배양 후에, FBS를 첨가하지 않은 무혈청 배지로 교체하여 시약을 처리하여 배양 후, 세포를 모아 $32 \mu l$ lysis buffer $(137 \mathrm{mM} \mathrm{NaCl}, 15 \mathrm{mM}$ EGTA, $0.1 \mathrm{mM}$ sodium orthovanadate, $15 \mathrm{mM} \mathrm{MgCl}, 0.1 \%$ Triton X-100, $25 \mathrm{mM}$ MOPS, $100 \mathrm{mM}$ phenylmethylsulfonyl fluoride, and $20 \mathrm{mM}$ leupeptin, $\mathrm{pH}$ 7.2)를 첨가하고 5 분 간격 으로 15 초 동안 3 번 vortex하여 세포를 파쇄한 후 $13,000 \mathrm{rpm}$, $4^{\circ} \mathrm{C}, 15$ 분간 원심 분리하여 시료를 준비하였다. 시료는 562 $\mathrm{nm}$ 에서 흡광도를 측정하여 단백질을 정량하였으며, $10 \% \mathrm{so}-$ dium dodecyl sulfate polyacrylamide gel electrophoresis (SDS-PAGE)에서 단백질을 분리한 후, immobilon membrane (Milipore, Bedford, MA)으로 transfer하였다. Membrane은 5\% milk/TBST (20 mM Tris-HCL, $137 \mathrm{mM} \mathrm{NaCl}$, 0.1\%Tween 20, pH 7.4)로 실온에서 1시간 유지한 후, PARP (Santa Cruz, $\mathrm{CA}, \mathrm{USA}$ )와 actin (Sigma, Louis, MO)을 희석한 5\% milk/TBST로 실온에서 12시간 유지하였다. Anti-mouse 또는 rabbit Ig horseradish peroxidase/TBST (Amersham Buckinghamshire, England)로 1시간 반응 후 Enhanced Chemiluminoscence (ECL, Pierce, IL, USA)용액을 가하여 발 색시켜서 단백질을 확인하였다.

\section{결과 및 고찰}

신장암세포에서 외인성 세포사멸 신호기전에 의한 세포사멸 에서의 $\mathrm{APC}$ 의 효과 확인

TRAIL, TNF-a와 cyclohexamide 그리고 FAS는 외인성 신호전달을 통해 종양세포의 사멸을 일으키는 것으로 알려 져 있다 $[8,12,15]$. 본 연구에서 외인성 신호전달을 통한 세포 사멸에 있어서의 $\mathrm{APC}$ 의 역할을 확인하였다. 인간의 신장암 세포에 $\mathrm{APC}$ 를 30 분간 전처리 한 후, 각각의 세포사멸을 일 으키는 $100 \mathrm{ng} / \mathrm{ml}$ TRAIL, $20 \mathrm{ng} / \mathrm{ml} \mathrm{TNF-a}$ 와 $10 \mu \mathrm{g} / \mathrm{ml}$ cyclohexamide (CHX), 그리고 $500 \mathrm{ng} / \mathrm{ml} \mathrm{FAS를} \mathrm{24시간} \mathrm{동}$ 안 처리하였다. TNF- $a$ 와 $\mathrm{CHX}$, 혹은 FAS에 의한 세포사멸 은 인간 신장암세포에서 유의적으로 일어났으나, $\mathrm{APC}$ 는 이 러한 세포사멸을 억제시키지는 못하였다(Fig. 1). 인간 신장 암세포는 TRAIL에 저항성을 가지는 암세포로 알려져 있듯 이 TRAIL에 의한 세포사멸은 확인할 수 없었다(Fig. 1). 본 연구결과를 통해서 $\mathrm{APC}$ 는 신장암세포에서 외인성 신호전 달경로를 통한 세포사멸에는 아무런 영향을 미치지 않는다 는 것을 확인하였다.

TRAlL 민감성을 가지는 뇌 암세포인 T98G와 유방암세포 인 MDA231세포에서의 APC 세포사멸 조절 여부

APC에 의한 human umbilical vein endothelial (HUVE) 세포의 세포보호(cytoprotective) 능력은 $\mathrm{APC}$ 에 의한 Egr1/ERK 활성화를 통한 TRAIL 발현 억제 때문에 야기된다 [13]. TRAIL에 의한 세포사멸에 APC의 역할을 규명하기 위하 여 TRAIL 에 민감성을 가지는 인간 뇌암세포인 T98G세포와 인간 유방암세포인 MDA231세포를 사용하여 확인하였다. $\mathrm{APC}$ 를 30 분간 전처리 한 후, $30 \mathrm{ng} / \mathrm{ml}$ TRAIL을 24 시간 동안 처리하였다. TRAIL은 두 가지 세포에서 모두 세포사멸을 유 의적으로 증가시켰으나 $\mathrm{APC}$ 는 두 가지 세포에서 모두 세포사 멸을 억제하지는 못하였다(Fig. 2). 본 결과는 TRAIL 매개의 세포사멸에 APC가 아무런 영향을 미치지 못함을 제시한다.

암세포사멸을 위한 약물병합처리에 의한 세포사멸에 있어서 의 $\mathrm{APC}$ 의 조절

외인성 신호전달체계를 통한 종양세포의 사멸 이외의 항암

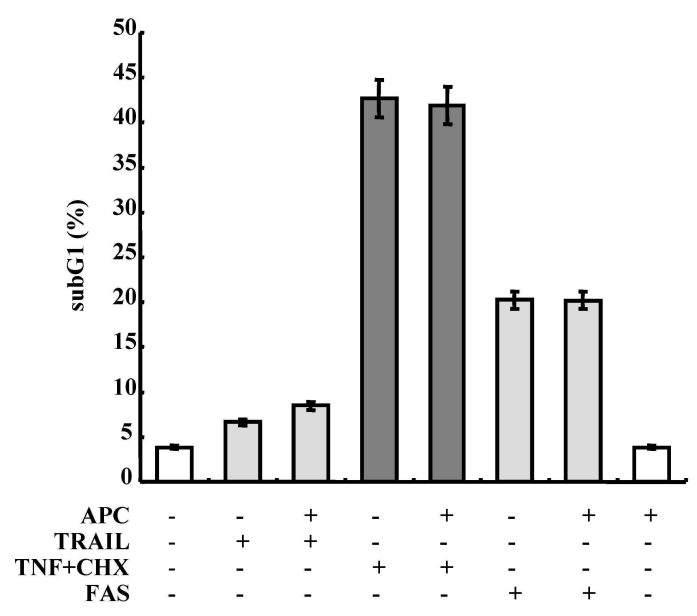

Fig. 1. Effect of APC on extrinsic pathway activated cell death. Caki cells were pretreated with $100 \mathrm{nM}$ activated protein $\mathrm{C}$ (APC) for $30 \mathrm{~min}$, and then treated with $100 \mathrm{ng} / \mathrm{ml}$ TRAIL, $20 \mathrm{ng} / \mathrm{ml}$ TNF-a plus $10 \mu \mathrm{g} / \mathrm{ml}$ cyclohexamide (CHX), and $500 \mathrm{ng} / \mathrm{ml}$ agonistic FAS antibody for $24 \mathrm{hr}$. Apoptosis was analyzed as a subG1 fraction by FACS. The data represent three independent experiments. 

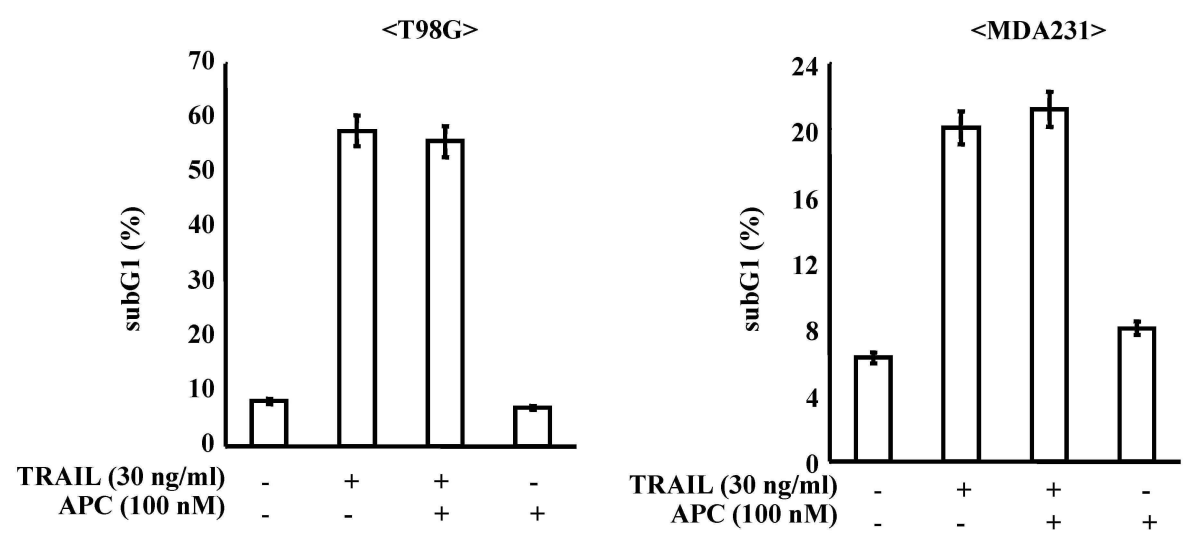

Fig. 2. APC has no effect on TRAIL-induced apoptosis in human glioma T98G and human breast carcinoma MDA231 cells. T98G and MDA231 cells were pretreated with $100 \mathrm{nM}$ APC for $30 \mathrm{~min}$, and then added with $30 \mathrm{ng} / \mathrm{ml}$ TRAIL for $24 \mathrm{hr}$. Apoptosis was analyzed as a subG1 fraction by FACS. The data represent three independent experiments.
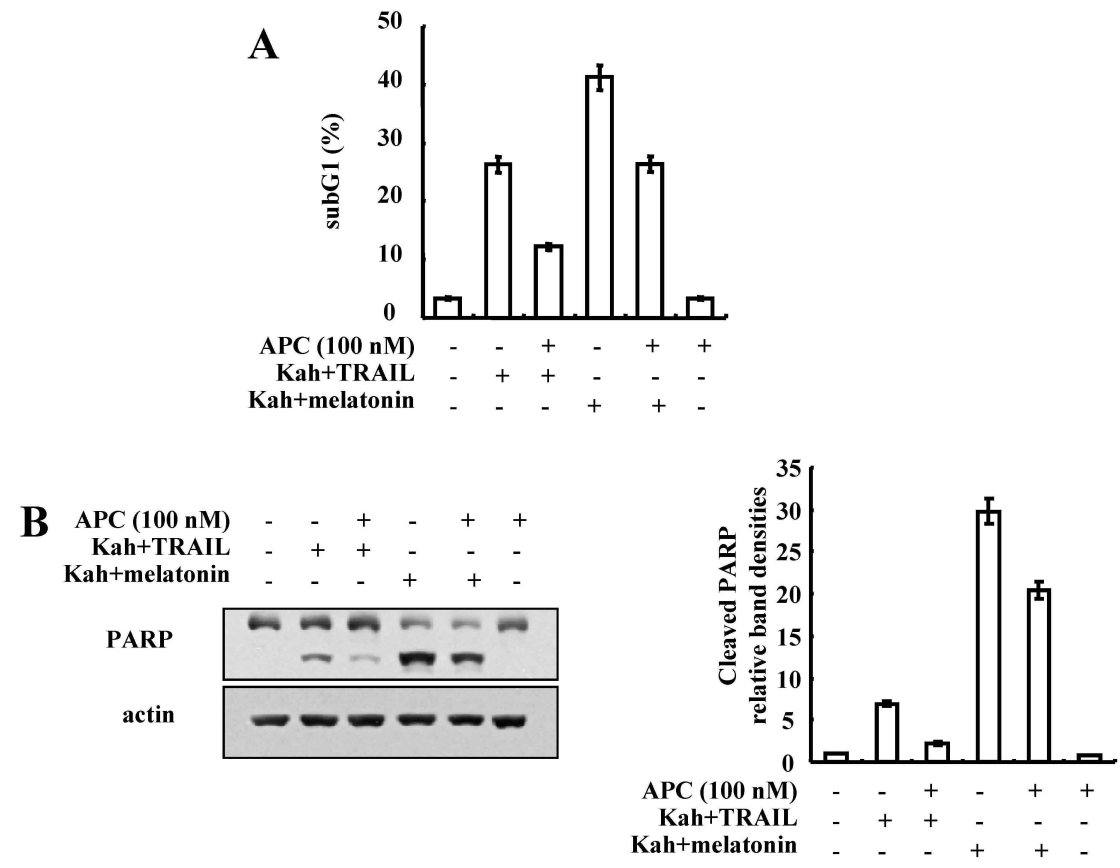

Fig. 3. APC inhibits Kahweol plus TRAIL and Kahweol plus melatonin-induced apoptosis in human renal carcinoma Caki cells. Caki cells were pretreated with $100 \mathrm{nM}$ APC for $30 \mathrm{~min}$, and then stimulated with $20 \mu \mathrm{M}$ kahweol plus $100 \mathrm{ng} / \mathrm{ml}$ TRAIL and $10 \mu \mathrm{M}$ kahweol plus $1 \mathrm{mM}$ melatonin for $24 \mathrm{hr}$. Apoptosis was analyzed as a subG1 fraction by FACS (A). PARP and actin protein expression were determined using Western blotting. Relative levels of each protein in cleaved PARP were shown as a relative densitometric value of each protein using the Bio-Rad Gel Doc System (B). The data represent three independent experiments.

약물의 병합처리를 통한 종양세포의 사멸에는 $\mathrm{APC}$ 가 어떠한 영향을 미치는 가를 확인해 보았다. 이전 연구에서, 커피의 추출물 중 한 성분인 kahweol과 TRAIL의 병합처리는 신장암 세포에서 유의적인 세포사멸을 일으키는 것으로 본 연구실에 서 발표한 바 있다[15]. 또한, kahweol과 생체시계 호르몬으로 알려진 melatonin을 병합 처리하면 역시 종양세포의 사멸을 유도한다고 본 연구실에서 발표하였다[16]. 따라서 이러한 두
가지 약물을 병합처리를 통한 종양세포의 사멸에서의 $\mathrm{APC}$ 의 역할을 규명하고자 실험하였다. 이전 보고와 같이, 신장암세 포에서 두 가지 약물의 병합처리는 유의적인 세포사멸을 일으 켰고, 흥미롭게도 $\mathrm{APC}$ 의 전처리는 이러한 세포사멸을 유의적 으로 감소시키는 것을 확인하였다(Fig. $3 \mathrm{~A})$. Apoptosis의 biomarker인 caspase-3의 기질로 알려진 PARP의 분절을 확인함 으로써 $\mathrm{APC}$ 의 anti-apoptotic 효과를 확인하였다. Kahweol과 
TRAIL 및 kahweol과 melatonin 병합처리에 의한 PARP의 분 절이 $\mathrm{APC}$ 에 의해 부분적으로 억제되는 것을 확인하였다(Fig. $3 \mathrm{~B})$.

$\mathrm{APC}$ 에 의한 저산소 상태 brain endothelium에서 직접적인 anti-apoptotic 효과는 p53 전사 억제, Bax/Bcl-2 비율조절 및 caspase-3 활성화 억제를 통하여 야기한다[4]. 본 연구에서는 $\mathrm{APC}$ 는 외인성 신호전달 경로만을 통한 암세포의 세포사멸에 는 아무런 영향을 미치지 않지만, 항암 약물의 병합처리를 통 한 암세포 사멸은 부분적으로 억제시키는 기능을 확인할 수 있었다. 비록 본 연구결과에서는 $\mathrm{APC}$ 의 정확한 antiapoptotic 기전에 대한 결과는 보다 더 많은 실험이 요구 되지 만 cell death receptor 매개의 세포 사멸에서는 APC의 세포 보호작용을 확인 할 수 없었다. 하지만 항암제와의 병합처리 시 APC의 세포보호 효과 즉 anti-apoptotic 효과를 처음으로 확인 하였다. $\mathrm{APC}$ 에 의한 항암작용 증진 기전 및 효과에 대한 연구는 더 많은 실험을 통하여 이루어 져야 한다고 생각된다.

\section{References}

1. Altinbas, M., Coskun, H. S., Er, O., Ozkan, M., Eser, B., Unal, A., Cetin, M. and Soyuer, S. 2004. A randomized clinical trial of combination chemotherapy with and without low-molecular-weight heparin in small cell lung cancer. $J$. Thromb. Haemost. 2, 1266-1271.

2. Beaulieu, L. M. and Church, F. C. 2007. Activated protein $\mathrm{C}$ promotes breast cancer cell migration through interactions with EPCR and PAR-1. Exp. Cell Res. 313, 677-687.

3. Bezuhly, M., Cullen, R., Esmon, C. T., Morris, S. F., West, K. A., Johnston, B. and Liwski, R. S. 2009. Role of activated protein $\mathrm{C}$ and its receptor in inhibition of tumor metastasis. Blood 113, 3371-3374.

4. Cheng, T., Liu, D., Griffin, J. H., Fernández, J. A., Castellino, F., Rosen, E. D., Fukudome, K. and Zlokovic, B. V. 2003. Activated protein $\mathrm{C}$ blocks p53-mediated apoptosis in ischemic human brain endothelium and is neuroprotective. Nat. Med 9, 338-342.

5. Chew, H. K., Wun, T., Harvey, D., Zhou, H. and White, R. H. 2006. Incidence of venous thromboembolism and its effect on survival among patients with common cancers. Arch Intern. Med 166, 458-464.

6. Donati, M. B. 2009. Thrombosis and cancer: Trousseau syndrome revisited. Best Pract. Res. Clin. Haematol. 22, 3-8.

7. Esmon, C. T., Vigano-D'Angelo, S., D'Angelo, A. and Comp, P. C. 1987. Anticoagulation proteins C and S. $A d v$. Exp.
Med Biol. 214, 47-54.

8. Esmon, N. L., Owen, W. G. and Esmon, C. T. 1982. Isolation of a membrane-bound cofactor for thrombin-catalyzed activation of protein C. J. Biol. Chem 257, 859-864.

9. Falschlehner, C., Emmerich, C. H., Gerlach, B. and Walczak, H. 2007. TRAIL signalling: decisions between life and death. Int. J. Biochem Cell Biol. 39, 1462-1475.

10. Klerk, C. P., Smorenburg, S. M., Otten, H. M., Lensing, A. W., Prins, M. H., Piovella, F., Prandoni, P., Bos, M. M., Richel, D. J., van Tienhoven, G. and Buller, H. R. 2005. The effect of low molecular weight heparin on survival in patients with advanced malignancy. J. Clin. Oncol. 23, 2130-2135.

11. Kobayashi, H., Moniwa, N., Gotoh, J., Sugimura, M. and Terao, T. 1994. Role of activated protein $\mathrm{C}$ in facilitating basement membrane invasion by tumor cells. Cancer Res. 54, 261-267.

12. Nagata, S. 1994. Apoptosis regulated by a death factor and its receptor: Fas ligand and Fas. Philos. Trans. R. Soc. Lond B. Biol. Sci. 345, 281-287.

13. O'Brien, L. A., Richardson, M. A., Mehrbod, S. F., Berg, D. T., Gerlitz, B., Gupta, A. and Grinnell, B. W. 2007. Activated protein $C$ decreases tumor necrosis factor related apoptosis-inducing ligand by an EPCR- independent mechanism involving Egr-1/Erk-1/2 activation. Arterioscler. Thromb. Vasc. Biol. 27, 2634-2641

14. Pajak, B., Gajkowska, B. and Orzechowski, A. 2005. Cycloheximide-mediated sensitization to TNF-alpha-induced apoptosis in human colorectal cancer cell line COLO 205; role of FLIP and metabolic inhibitors. J. Physiol. Pharmacol. 56, 101-118.

15. Um, H. J., Oh, J. H., Kim, Y. N., Choi, Y. H., Kim, S. H., Park, J. W. and Kwon, T. K. 2010. The coffee diterpene kahweol sensitizes TRAIL-induced apoptosis in renal carcinoma Caki cells through down-regulation of Bcl-2 and c-FLIP. Chem Biol. Interact. 186, 36-42.

16. Um, H. J., Park, J. W. and Kwon, T. K. 2011. Melatonin sensitizes Caki renal cancer cells to kahweol-induced apoptosis through CHOP-mediated up-regulation of PUMA. J. Pineal Res. 50, 359-366.

17. Varki, A. 2007. Trousseau's syndrome: multiple definitions and multiple mechanisms. Blood 110, 1723-1729.

18. Xue, M, Thompson, P., Kelso, I. and Jackson, C. 2004. Activated protein $\mathrm{C}$ stimulates proliferation, migration and wound closure, inhibits apoptosis and upregulates MMP-2 activity in cultured human keratinocytes. Exp. Cell Res. 299, 119-127. 
초록 : 종양세포의 사멸에 있어서의 activated protein C의 효과

민경진 ${ }^{1} \cdot$ 배종섭 $^{2} \cdot$ 권택규 ${ }^{*}$

( ${ }^{1}$ 계명대학교 의과대학 면역학교실, ${ }^{2}$ 경북대학교 약학대학 약학연구소)

본 연구에서는 항응고제로서의 역할을 가지면서 또한 혈액응고와는 관련 없는 종양세포의 전이 등을 조절하 는 것으로 알려진 activated protein C (APC)가 종양세포의 사멸에는 어떠한 영향을 미치는 지에 대한 연구를 수행하였다. Tumor necrosis factor (TNF)- $a$ 와 cyclohexamide를 병합 처리하거나 FAS를 처리하게 되면 인간 신 장암세포인 Caki에서는 유의적인 세포사멸이 일어난다. 하지만, APC는 이러한 세포사멸에 아무런 영향을 미치 지 못하였다. 또한 TRAIL을 인간 뇌 암세포인 T98G와 유방암세포인 MDA231세포에 처리하여 세포사멸을 일으 켰을 때에도 APC는 세포사멸을 조절하지 못하였다. 그러나, TRAIL에 대한 민감도를 증가시키기 위한 kahweol 과 TRAIL의 병합처리나, kahweol과 malatonin의 병합처리에 의한 신장암세포의 사멸은 APC에 의해 유의적으 로 억제되는 것을 확인하였다. 따라서, 이는 $\mathrm{APC}$ 가 항암치료의 효율성을 조절 할 수 있는 가능성을 가짐을 의 미한다. 